\title{
Kampen om klimaet
}

Nikolaj Petersen

\section{Meilstrups bog giver ikke blot et kvalificeret bud på, hvorfor COP15 blev et topmøde, der løb løbsk. Den er også central for forståelsen af for- muleringen af dansk udenrigspolitik og i bredere forstand et bidrag til forståelsen af mål og strate- gier i dansk udenrigspolitik i Fogh-perioden}

Per Meilstrup: Kampen om klimaet. Historien om et topmøde der løb løbsk. People’s Press, Københaun 2010. 305 sider.

'Højt at flyve - dybt at falde' kunne være en alternativ titel på denne fremragende bog om Danmarks største diplomatiske satsning nogensinde, FN's klimatopmøde COP15 i København. Forfatteren, der er klimadirektør ved tænketanken Mandag Morgen og indtil 2007 var ansat i Miljøstyrelsen, har minutiøst fulgt mødeforberedelserne og har undervejs og efterfølgende haft lange samtaler med Connie Hedegaard og Lars Løkke Rasmussen og interviewet "en lang række af centralt placerede embedsmænd fra Udenrigs-, Stats- og Klima- og Energiministeriet, som udgjorde grundstammen i
Danmarks forberedelsesarbejde og forhandlerteamet i Bella Center".

Bogen er bygget op omkring udsagn fra disse kilder, som bortset fra de to ministre er anonymiserede, dog således at deres organisationstilhør som oftest er angivet. Uden at der er foretaget en optælling, er det indtrykket, at forfatterens kilder har flydt rigeligere fra klimasiden end fra Statsministeriet; således har Anders Fogh Rasmussen ikke medvirket, ligesom det står uklart, i hvilket omfang den centrale embedsmand, departementsråd Bo Lidegaard, har bidraget. Det samme gælder i øvrigt hans med- og modspiller, Klima- og Energiministeriets internationale hovedforhandler Thomas Becker. Denne tyngdefordeling afspejler også forfatterens sympatier, som mere er med klimafolkene end med 
'strategerne' i Statsministeriet, mere med bogens heroine Connie Hedegaard end med Fogh og Løkke Rasmussen. Nogen egentlig bias er der dog ikke tale om.

Uanset dette udgør den udbredte brug af anonyme kilder, der bogen igennem konsekvent gengives i citationstegn, naturligvis et metodisk problem, der primært må vurderes på, om fremstillingen adderer op til en plausibel fortælling, der stemmer overens med, hvad vi ellers ved, og om den giver løsninger på de 'gåder', som har omhyllet de danske konferenceforberedelser og det utrolige konferenceforløb. Der er ingen tvivl om, at bogen lever op til disse krav.

Den er dertil velskrevet og elementært spændende som nogen politisk thriller. Strukturen er enkelt, men effektivt bygget op af kapitler, der følger begivenhederne hver af konferencens 13 dage, vekslende med kapitler, der tegner udviklingen i dansk klimapolitik og mødeforberedelserne fra 2004, hvor den belastede miljøminister Hans Chr. Schmidt blev afløst af Connie Hedegaard.

Ministerskiftet var første trin i Anders Fogh Rasmussens forvandling fra miljøskeptiker til international klima-aktivist. Andet trin var den private lære, han drog af Muhammed-krisen, nemlig at Vesten måtte gøre sig uafhængig af olien fra Mellemøsten og derfor satse på vedvarende energikilder, mens det tredje trin var beslutningen om at lægge billet ind på formandskabet for COP15, det møde der var udset til at vedtage en ny, omfattende international klimaaftale som opfølgning af Kyoto-protokollen af 1997.

Ideen kom fra Thomas Becker, blev grebet af Connie Hedegaard og købt af Fogh Rasmussen som et nationalt branding-projekt. Efter en omfattende diplomatisk indsats lykkedes det i foråret 2007 Danmark at tilkæmpe sig formandskabet, ikke mindst fordi Connie Hedegaard gennem den såkaldte Grønlandsdialog havde skabt sig en stærk position i international klimapolitik.

\section{Grunden til fiasko}

Allerede her - understreger forfatteren - blev grunden lagt til formandskabsfiaskoen i december 2009, idet Fogh og Statsministeriets embedsmænd fra begyndelsen betragtede topmødet som et nationalt prestigeprojekt inden for rammerne af den aktivistiske udenrigspolitik, mens Connie Hedegaard og Klima- og Energiministeriet så formandskabet som en international opgave, som Danmark havde påtaget sig at løse på COP-processens præmisser.

Helt fra 2007 stod de to opfattelser mod hinanden, idet et forsøg på at aftale en integreret organisation til koordinering af mødeforberedelserne ikke skabte den fornødne klarhed. Aftalen indebar et bemærkelsesværdigt magtafkald fra Udenrigsministeriets side, ved at Per Stig 


\section{LITTERATUR}

Møller uden sværdslag overlod forhandlingsledelsen til sin protegé Connie Hedegaards ministerium, således at Udenrigsministeriet 'kun' fik ansvaret for konferencelogistikken og public diplomacy i forbindelse med mødet. Statsministeriet skulle i henhold til det aftalte svæve over vandene og have den overordnede koordination, blandt andet ved at et interdepartementalt COP15-sekretariat blev placeret dér under ledelse af Bo Lidegaard. Uklarheden i dette arrangement kom frem i Lidegaards svar på et spørgsmål fra "en af Miljøministeriets embedsmænd" om det betød, at han rangerede over Connie Hedegaard. Hertil skal Lidegaard have svaret: "Nærmest ja."

\section{Efterfølgende magtspil}

Bogens mest fascinerende, men bestemt ikke mest opbyggelige afsnit, drejer sig om det efterfølgende magtspil mellem de to ministre og deres topembedsmænd - med Statsministeriet som den givne vinder på den korte bane, men også som taberen af 'terrinen' på den lange. Man har næppe tidligere set et så klart dokumenteret eksempel på bureaukratisk infight om indflydelse og status i dansk udenrigspolitik.

Som antydet var der ikke blot tale om en kamp om 'turf' ('territorium'), men også om principielle meningsforskelle mellem Statsministeriet og Klima- og Energiministeriet. For det første fortsatte den grundlæggende uenighed om formandskabets indhold. Statsministeriet så rollen som et aktivt lederskab til fremme af danske og vestlige værdier og som en lejlighed til at promovere Danmark internationalt, mens Klima- og Energiministeriet (støttet af FN's klimasekretariat og Udenrigsministeriet) understregede rollen som neutral 'facilitator' af enighed mellem de deltagende lande og inden for den løbende COP-proces. Denne bestod primært i arbejdet i to arbejdsgrupper, der skulle udarbejde tekster til en generel klimakonvention og en specifik aftale om videreførelse af Kyoto-protokollen.

I den sidste fase blev det til uenighed, om Danmark skulle lægge sit eget politiske udspil til en aftaletekst på bordet eller ej. For det andet var der uenighed om håndteringen af USA, som Connie Hedegaard var rede til at presse langt hårdere, end Statsministeriet kunne gå med til. For det tredje opstod uenighed om rammen om en ny klimaaftale, hvor Statsministeriet efterhånden blev indstillet på at søge en ny aftale ved at gå uden om Kyoto-protokollen og COP-processen, hvad Klimaministeriet opfattede som en fatal fejltagelse.

Konsekvensen af disse divergenser blev, at der blev skabt tvivl om, hvem der egentlig repræsenterede Danmark, og hvad formandskabets strategi gik ud på. Uklarheden blev ikke mindre af, at Thomas Becker blev sat ud af spillet af en bilagssag kort før konferencens start. 


\section{De tretten dage}

De to parter var dog enige om én ting, nemlig at 'tale konferencen op', hvorved der skabtes et forventningspres, som konferencen ikke kunne leve op til.

Bogens andet hovedtema er de tretten dages forhandlinger (eller hvad man nu skal kalde dem). Alt, hvad der kunne gå galt, gik nemlig galt. Udenrigsminister Hillary Clintons bemærkning til den netop ankomne præsident Barack Obama, at dette var det værste møde, hun havde deltaget i siden 8 . klasses elevråd, illustrerer situationen på den sidste officielle forhandlingsdag.

Kaos startede allerede på konferencens anden dag med, at kineserne lækkede et dokument, som Statsministeriet - imod Klimaministeriets stærke advarsel - tidligere havde fordelt til en mindre gruppe lande. Dokumentet havde stærk slagside til ilandssiden, men var ikke længere fuldt dækkende for den danske holdning. Men resultatet blev ikke desto mindre, at lækket med et slag umuliggjorde det danske formandskab i ulandenes øjne. (Det er et underligt træk ved analysen, at forfatteren ikke standser op her og overvejer den pågældende journalists rolle. Var det ok at publicere et ganske vist autentisk, men uaktuelt dokument, før dokumentets status var afklaret?).

Herefter var det kun op ad bakke, og det danske formandskab befandt sig snart i en reel Catch 22 situation.
På den ene side var forhandlingerne i COP's to arbejdsgrupper ikke skredet langt nok frem til, at der forelå et reelt grundlag for et konferencedokument; på den anden side satte en kompakt ulandsgruppe sig voldsomt imod formandskabets intention om at søge dødvandet brudt ved at kaste et dansk kompromispapir ind i debatten.

Statsminister Lars Løkke Rasmussen, der præsiderede over plenardebatten de sidste dage, blev i særlig grad genstand for ulandenes massive mistillid, som ikke blev mindre af de mange tegn på hans fremmedhed over for den proces, han var sat til at lede i havn. Også støtten fra de vestlige lande til formanden var behersket, og USA, Storbritannien og EU advarede ham på et tidspunkt i en samlet aktion mod at fremlægge det danske kompromisforslag.

I denne umulige situation besluttede statsministeren ikke at stikke piben ind, men at bruge de tilstedeværende over hundrede stats- og regeringschefer til at presse et resultat igennem. Mens formandskabet gjorde et sidste forsøg på at afslutte COP-forhandlingerne, indledtes forhandlinger på kryds og tværs mellem stats- og regeringscheferne, der gradvis skabte den magre Copenhagen Accord, der blev konferencens officielle resultat. Det var først i denne fase, at det danske formandskab fik lagt et papir på bordet, men i en stærkt barberet version. Den 'store' danske kompromistekst, som der 


\section{LITTERATUR}

havde været ofret utallige arbejdstimer på at udarbejde, omskrive og ajourføre, blev ikke lagt på bordet, men kunne efter forfatterens vurdering have været grundlag for et andet og bedre resultat af COP15.

Ingen har formentlig et fuldt overblik over den forvirrende og improviserede mødeaktivitet de sidste konferencedage. Men forfatteren har sikkert ret i, at det her gik op for alle, at 'en ny verdensorden' var født.

Ikke blot markerede Kina sig som en uomgængelig supermagt, men også de store ulande, Brasilien, Indien, Sydafrika med flere markerede sig som tunge spillere på den internationale bane. Den måske mest sigende enkelthændelse var, da præsident Obama og udenrigsminister Clinton i jagten på den kinesiske delegationsleder Wen Jiabao gatecrashede et møde mellem denne og disse tre store ulandes ledere, Lula, Singh og Zuma.

Efter dette møde og umiddelbart inden hjemrejsen med Air Force One proklamerede Obama noget forhastet, at der nu var opnået enighed. Som forfatteren bemærker: "Netop dette øjeblik skulle have været Danmarks og Danmarks statsministers golden hour. Kronen på værket".

Det blev det ikke. Uanset det magre indhold i the Copenhagen Accord viste det sig uhyre vanskeligt at få den vedtaget i plenarforsamlingen, hvor kritikken af den danske mødeledelse fortsatte til det sidste. Det var måske sigende, at hverken Hedegaard eller Løkke var til stede, da slutdokumentet blev formelt vedtaget. De var taget hjem for at sove.

\section{Ikke Danmarks skyld}

Afslutningsvis konkluderer forfatteren, at det magre udbytte af COP15 ikke var Danmarks skyld, idet magtspillet mellem Kina og USA og konflikterne mellem i- og ulande lagde sig i vejen for den politiske vilje, der var forudsætningen for en substantiel aftale.

Alligevel er han stærkt kritisk over for den danske håndtering af formandsrollen. Det lykkedes ikke "at repræsentere parterne og formidle den størst mulige grad af enighed mellem parterne i en veltilrettelagt proces". Og samtidig slog "Danmarks forsøg på at agere fødselshjælper for en global konsensus og derigennem skabe sig en markant global position" også fejl. Både under forberedelserne og selve konferencen begik formandskabet en række fejl, som var "ansvarspådragende”. For det første skruede det forventningerne voldsomt i vejret, for det andet valgte det en kontroversiel strategi for at nå i mål. For det tredje overhørte det råd og advarsler fra partnere og allierede, da faren for fiasko blev overhængende.

Mejlstrup går ikke dybere i sin kritik af formandskabet. Man kunne imidlertid gå videre og argumente- 
re, at fiaskoen ikke var en tilfældighed skabt af ugunstige ydre og indre forhold, men et logisk konsekvens af den Fogh'ske udenrigspolitik med dens vægt på promovering af Danmark som en strategisk aktør på verdensplan.

I dette perspektiv var det Foghs 'hijacking' af klimadagsordenen og specielt COP15 i 2006-07, der skabte problemet. Hvis Connie Hedegaard, der som den eneste slipper for kritik i denne bog, skal bebrejdes noget, kunne det være, at hun og hendes embedsmænd i bestræbelsen for at gøre noget ved klimaspørgsmålet koblede sig til den Fogh'ske dagsorden og dermed udsatte sig for at miste kontrollen over konferenceforberedelserne. En anden svaghed ved klimasidens strategi, som forfatteren kunne have understreget kraftigere, var dens afhængighed af COP-processen, der viste sig ikke at kunne levere, da det kom til stykket.

Meilstrups bog giver ikke blot et kvalificeret bud på, hvorfor COP15 blev "et topmøde der løb løbsk". Den er også uhyre central for forståelsen af formuleringen af dansk udenrigspolitik ved sin detaljerede dokumentation af relationerne mellem to ministerier og af Statsministeriets ambitioner om en ledende udenrigspolitisk rolle.

I bredere forstand er den et fornemt bidrag til forståelsen af mål og strategier i dansk udenrigspolitik i Fogh-perioden.

Nikolaj Petersen er professor emeritus, Aarhus Universitet. 